\author{
Isak Karabegović \\ Full Professor \\ University of Bihać \\ Faculty of Technical Engineering \\ Bosnia and Herzegovina \\ Bekir Novkinić \\ University of Bihać \\ Faculty of Technical Engineering \\ Bosnia and Herzegovina \\ Ermin Husak \\ Teaching Assistant \\ University of Bihać \\ Faculty of Technical Engineering \\ Bosnia and Herzegovina
}

\section{Experimental Identification of Tool Holder Acceleration in the Process of Longitudinal Turning}

Planning of the modern manufacturing systems that would be suitable for the most demanding cutting processes requires analysis of all technical and technological process parameters by applying scientific methods, modeling and optimal conditions of machining process and systems defining. In order to secure the planned functioning of machine tools they need to be sufficiently resistant and stable at all influences which are exposed in the cutting process. Because high number of influence factors to the cutting process, it is very difficulty to determine most influence parameters of the cutting process by analytical model. For this reason it is necessary to apply the experimental measurements and analysis of the results which will be used for creating fudantion for cutting force identification and which is indispensable in the development of new machine tools and improving existing machining systems. Objective of this paper is to find mathematical algorithm of tool holder acceleration $a_{N A}=$ $f\left(\sigma_{z}, v, \delta\right)$ in function of machined material strength, cutting velocity and depth of cut. Experimental investigation of tool holder acceleration during turning process has done for three different types of steel: 9SMn28, S355JOG3 and C45E.

Keywords: machine tool, turning, modeling, acceleration, tool holder.

\section{INTRODUCTION}

In this paper an experimental identification of parameters on the tool holder in the longitudinal turning is given, and then the most influential parameters are identified by the method of mathematical modeling. This approach of identifying the most influential parameters on the occurrence of the phenomenon of vibration on the tool holder is very helpful because it allows the cutting takes place under constant supervision, which is manifested on the surface quality and machining system in general.

The design of modern manufacturing systems on which it would be possible to run the most demanding cutting processes requires the process of analysis of all technical - technological parameters of the process by applying of scientific methods, modelling and defining the optimal conditions of machining processes and systems $[1,2,3,4]$. Researches in the field of machine tools structures and their behaviour in operating conditions are point out the need to create more complex models $[6,8,9,10]$. Due to the large number of influencing factors on the process of cutting is very difficult to determine the most influential cutting process parameters using an analytical model.

Modelling of processing is the basis of optimization and defining of optimal processing conditions, which is unthinkable without first defining of a reliable mathematical model. Application of experimental

Received: June 2014 Accepted: March 2015

Correspondence to: Dr Isak Karabegović

Faculty of Technical Engineering,

Dr. Irfana Ljubijankića bb., 77000 Bihać, Bosnia and Herzegovina

E-mail: isak1910@hotmail.com measurements and analysis of the results is indispensable in the development of new machine tools and improvement of existing machining systems.

\section{SELECTING OF INPUT-OUTPUT PARAMETERS OF LONGITUDINAL TURNING PROCESSING}

In order to perform the experiment successfully, the identification and restriction of certain influential parameters of observed process are required.

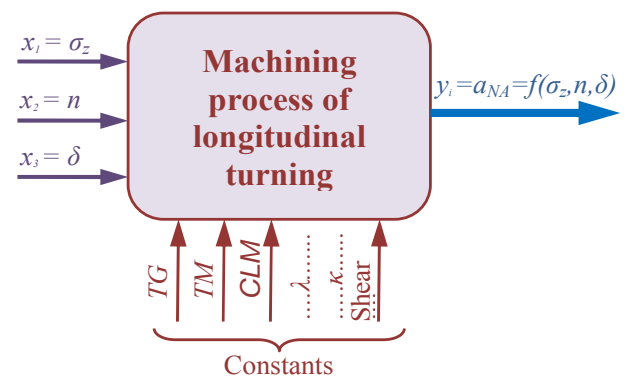

Figure 1. Parameters of (input-output) processes that were included in the experiment TG-tool geometry, TM-tool material, CLM- cooling and lubrication means

It is, in the first place, meant on defining only certain input variables as independently variable $x_{\mathrm{i}}$ as input into the process and defining of the functions of the output from the process $y_{i}$ which are of dependently variable size. This approach allows us a quality management of the machining process of longitudinal turning itself and moving towards the set modeling process $[5,6,9]$. Parameters of (input-output) processes that were included in the experiment are shown in Figure 1, where: $\sigma_{z}$ - tensile strength of the material 
$\left(\mathrm{N} / \mathrm{mm}^{2}\right), n$ - revolution number (rpm), $\delta$ - cutting depth $(\mathrm{mm})$ and $a$ - tool holder acceleration $\left(\mathrm{m} / \mathrm{sec}^{2}\right)$, while the other process parameters of longitudinal turning are considered as constants. In this research cutting feed is not taken as a variable because it has lower influence to vibration compared to other parameters used as variables. This parameter is used in our other researches.

In the experimental cutting process, the three different materials (9SMn28, S355JOG3, C45E) which have different chemical and mechanical properties were used. Physical values independently variable process parameters $\sigma_{z}, n$ and $\delta$ are shown in Table 1 .

\section{EXPERIMENTAL SETUP}

In an experimental research with the plan of experiment the performing a total of 12 experiments, that is measuring of the tool holder acceleration $a_{N A}$ is estimated, of which eight experiments with different values of the influential parameters and four with average values, Table 2. In order to perform the measurement in the first place, it is necessary to provide all the elements of a measuring system that would enable the measurement in the real time, which consists of: sensors, amplifiers, converters and computers [6].

For measurement of acceleration on the tool holder during longitudinal cutting was used lathe type "TOS TRENČIN", with a tool for external processing, with plate SPGX, with the distance from the tool holder for $25 \mathrm{~mm}$. Sensors (piezoelectric accelerometers) of type "METRIX" $100 \mathrm{mV} / \mathrm{g}$ are placed in the tool holder by magnet, and using A / D converter "SPIDER 8 '(Figure 4) connected by means of conductors. Since the planned modeling acceleration which will be a function of the material, cutting depth and velocity it needs to be calculated the total vibration $a_{N A}$ consisting of accelerations in directions $x, y$ and $z$ (Figure 3).

$$
a_{N A}=\sqrt{a_{x}^{2}+a_{y}^{2}+a_{z}^{2}}
$$

where: $a_{N A}$ - total vibration acceleration, $a_{x}, a_{y}, a_{z}$, vibration acceleration in $x, y$ and $z$ directions.

An overview of the measuring system and method of measuring acceleration on the tool holder, recording (Figure 5) and processing of data for the purpose of obtaining the total vibrations on the tool holder is given on Figure 2.

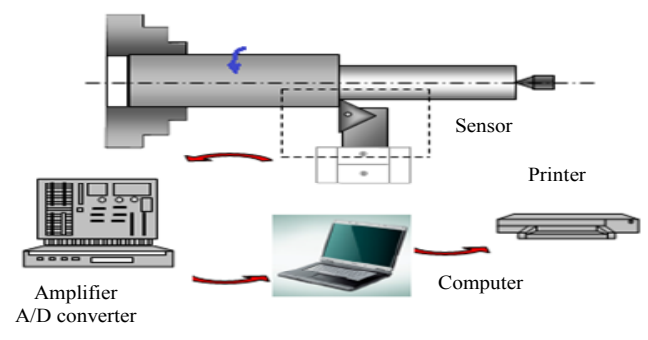

Figure 2. Measurement system and method of results Recording
Performing the experiment consists of the following: a work-piece (of diameter $\varnothing 30 \mathrm{~mm}$ and length 400 $\mathrm{mm}$ ) is placed in the chuck and spike on the processing machine, then the processing tool is set in tool holder (Figure 3), then the connecting cables connect sensors to measure acceleration in three directions with the measuring apparatus.

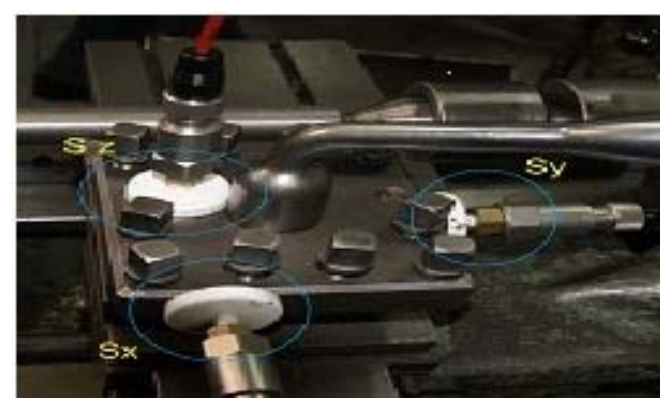

Figure 3. Sensors for measurning

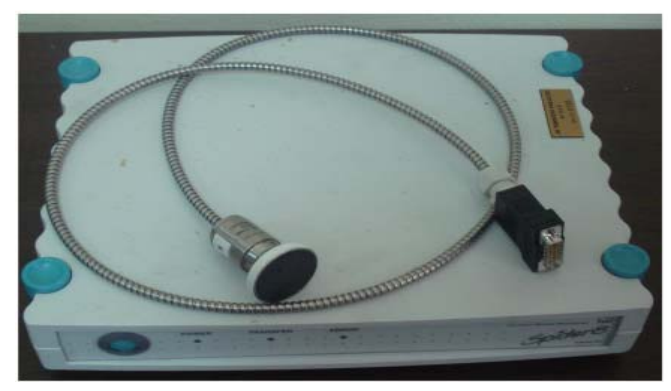

Fiqure 4. Sensor and A/D coverter

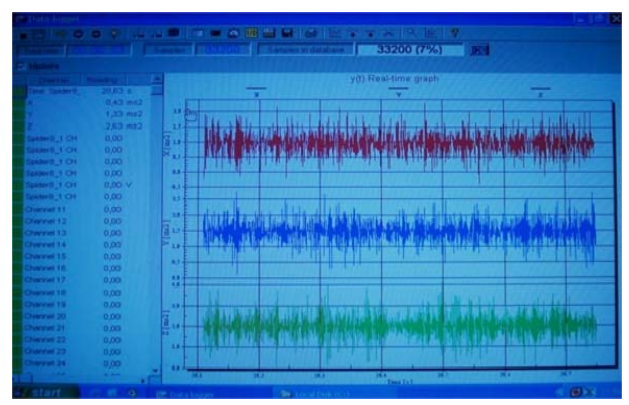

Figure 5. Measuring diagrams of acceleration in three direction

After this, longitudinal turning process is performed by a defined experiment plan (number of experiments, the size of the work-pieces, cooling method, etc.).

\section{ANALYSIS AND TESTING OF HOMOGENEITY OF THE EXPERIMENTAL RESULTS}

As we have already defined the input and output variables of the process as shown in Figure 1, as well as the variations of their values given in Table 1, the total of 12 experiments were performed, where the repetition of the experiment is just in a central point $\left(n_{0}=4\right)$ was performed [3,5]. Repeating of the experiment is necessary to accomplish the dispersion analysis of the experimental results (homogeneity of experiment, 
estimation of error of the experiment, the adequacy of the model, etc.).

Obtained experimental results for tool holder acceleration $\left(a_{N M}\right)$ with physical and coded values of selected influential parameters $x_{i}$ are shown in Table 2 .

Selected mathematical model for modeling of tool holder acceleration $\left(a_{N M}\right)$ is a mathematical model of the first order and in coded form with $a_{i}=y_{i}=f\left(x_{i}\right)$ as follows:

$Y=b_{o}+b_{1} X_{1}+b_{2} X_{2}+b_{3} X_{3}+b_{12} X_{1} X_{2}+b_{23} X_{2} X_{3}+$

$b_{13} X_{1} X_{3}+b_{123} X_{1} X_{2} X_{3}$

where: $X_{i}$ - influential parameters in coded form, $b_{i}$ regression coefficients.

After completion of the experiment it is necessary to check the source of dispersions, or check the homogeneity of the experiment in order to determine the differences in obtained numerical values. For our conditions we use Cochran's criterion to check dispersions' homogeneity (detailed description in the literature [3]) which has the form:

$$
K_{h}=\frac{\max S_{j}^{2}}{\sum_{j=1}^{N} S_{j}^{2}} \leq K_{t}\left(f_{j}, N\right)
$$

where:

$f_{j}$ - degree of freedom $\left(f_{j}=n-1=3\right)$,

$n_{j}$ - number of repetitions in the sample $\left(n_{j}=n_{0}=4\right)$,

$K_{t}$ - tabular value for the Cochran criterion,

Sample variance

$$
S_{j}^{2}=\frac{1}{n_{j}-1} \sum_{i=1}^{3}\left(y_{j i}-\bar{y}_{j}\right)^{2}
$$

Total variance of experiment

$$
\sum_{j=1}^{N} S_{j}^{2}=\frac{\sum_{j=1}^{N} \sum_{i=1}^{n}\left(y_{j i}-\bar{y}_{j}\right)^{2}}{\sum_{j=1}^{N}\left(n_{j}-1\right)}
$$

Bearing in mind that the repetitions of measurements was made only in items $9,10,11$, and 12 trials, and after obtaining the values of variables (3) and (4) in equation (2), we get that: $K_{h}=0.5354$.

According to data of $K_{t}\left(f_{j}=3, N=n_{0}\right)=0.781$ [3,5], with selected statistical probability $(\mathrm{P}=0.99)$ and using the condition given in equation ( 3 ) is:

$$
K_{h}=0,5354 \leq K_{t}(3,4)=0,684
$$

As can be seen from the expression (6) condition of Cochran's criterion which is given by the expression (3) is fulfilled, i.e. the dispersion of the experimental results is homogeneous and can proceed with the modeling of data obtained experimentally.

\section{ANALYSIS OF EXPERIMENTAL DATA OF THE PROCESS OF LONGITUDINAL TURNING}

In order to make a mathematical model of the process which is given by the expression (2) accepted, it is necessary to calculate the values and check the significance of regression coefficients of the model $\left(b_{i}\right)$ and examine the adequacy of the model.

For the conditions of repetition of the experiment in the central point, the values of the regression model coefficients are obtained using the following expressions:

$$
\begin{aligned}
& b_{0}=\frac{1}{N} \sum_{j=1}^{N} X_{0 j} y_{j}=\frac{1}{N}\left(\sum_{j=1}^{N-n_{0}} X_{0 j} y_{j}+\sum_{j=n_{0}}^{N} X_{0 j} y_{0 j}\right) \\
& b_{i}=\frac{1}{N-n_{0}} \sum_{j=1}^{N} X_{i j} y_{j}, \text { for } i=1,2, \ldots, k, \\
& b_{i m}=\frac{1}{N-n_{0}} \sum_{j=1}^{N} X_{i j} X_{m j} y_{j}, \text { for } 1 \leq i<m \leq k,
\end{aligned}
$$

where:

$b_{0}, b_{i}, b_{i m} \quad$ - coefficients of a mathematical model,

$X_{i j}, X_{m j} \quad-$ coded quantities,

$N=2^{k}+n_{0} \quad-$ total number of trials,

$n_{0}-$ number of repeated experiments at the central point of the plan

$y_{o j}$ - results of experiments in the central point of the plan,

$y_{j}$ - results of experiments in the $N$-point plan or the $\left(N-n_{0}\right)$ point of plan.

The values obtained for model coefficients of the total acceleration of the tool holder $a_{N A}$ on the basis of Table 2 and equation (7), (8) and (9) and they are as follows:

$$
\begin{aligned}
& b_{0}=2,044 ; b_{1}=0,184 ; b_{2}=0,493 ; b_{3}=0,461 ; \\
& b_{12}=0,394 ; b_{23}=0,138 ; b_{13}=-0,199 ; b_{123}=0,160 ; \\
& F_{r i}=\frac{S_{b i}^{2}}{S_{0}^{2}} \geq F_{t}\left(f_{b i}, f_{2}\right)=F_{t}\left(1, f_{0}\right), \text { for } i=0,1,2, \ldots \mathrm{k}
\end{aligned}
$$

where:

Estimation of errors of $\mathrm{k}$. model

$$
S_{b 0}^{2}=\frac{N b_{0}^{2}}{f_{b 0}}, S_{b i}^{2}=\frac{\left(N-n_{0}\right) b_{i}^{2}}{f_{b i}}
$$

$$
F_{r 0}=\frac{N b_{0}^{2}}{S_{0}^{2}}, F_{r i}=\frac{\left(N-n_{0}\right) b_{i}^{2}}{S_{0}^{2}}, \text { for } \mathrm{i}=1,2, \ldots . ., \mathrm{k}
$$


Estimation of errors in the central point of experiment,

$$
S_{0}^{2}=\frac{\sum_{j=1}^{n_{0}}\left(y_{0 j}-\bar{y}_{0}\right)^{2}}{f_{0}}
$$

Arithmetic mean value of the measurement results $y_{0 j}$ in zero point plan,

$$
\bar{y}_{0}=\frac{\sum_{j=1}^{n_{0}} y_{0 j}}{n_{0}}
$$

$f_{b 0}=f_{b 1}=\ldots f_{b i}=f_{b k}=1$ - degree of freedom coeff. model,

$f_{0}=n_{0}-1=3-$ degree of freedom in the central point of the plan.

Using given expressions from (10) to (14) and by additional calculating of values, rating the significance of model coefficients is presented in Table 3, where in column "Verification" using the character "*" their significance is confirmed, and that are coefficients: $b_{0}, b_{1}, b_{2}, b_{3}$, and $b_{12}$.

The coefficients $b_{i}$ that are not significant in the further steps are excluded from the mathematical model in equation (1), so that the model now takes the form:

$$
Y=b_{0}+b_{2} X_{2}+b_{3} X_{3}+b_{12} X_{1} X_{2}
$$

The final mathematical model with the values of significant coefficients should now take the form:

$$
Y=2,044+0,493 X_{2}+0,461 X_{3}+0,394 X_{1} X_{2}
$$

After defining the function model $Y_{i}(16)$, the next step in processing the results of the experiment is determining the adequacy of the obtained model and calculate the coefficient of multiple regression $R$ as additional criteria adequacy.

In general case, the adequacy of the obtained mathematical model is verified by comparing the experimentally obtained values $y_{j}^{E}$ and calculated values $y_{j}^{R}$ obtained from the model, where the condition of the adequacy determined by F-criterion, which reads:

$$
\left.F_{a}=\frac{S_{a}^{2}}{S_{0}^{2}} \leq F_{t}\left(f_{a}, f_{0}\right), \text { for } S_{a}^{2}\right\rangle S_{0}^{2}
$$

or

$$
\left.F_{a}=\frac{S_{0}^{2}}{S_{a}^{2}} \leq F_{t}\left(f_{0}, f_{a}\right), \text { for } S_{0}^{2}\right\rangle S_{a}^{2}
$$

where:

$$
S_{a}^{2}=\frac{\sum_{j=1}^{N}\left(y_{j}^{E}-y_{j}^{R}\right)^{2}-\sum_{j=1}^{n_{0}}\left(y_{0 j}-\bar{y}_{0}\right)^{2}}{f_{a}}
$$

$\underline{f_{a}}=N-k-1-f_{0}=12-3-1-3=5, \quad$ - degree of freedom refers to the dispersion of adequacy

$F_{t}\left(f_{a}, f_{0}\right)=F_{t}(5,3)=28.2-\mathrm{F}$ - table value criteria.

Quadrat sum, e.i. an experiment error.

$$
\sum_{j=1}^{n_{0}}\left(y_{0 j}-\bar{y}_{0}\right)^{2}=S_{0}=S_{0}^{2} \cdot f_{0}
$$

When the value of expression (16), (18) and (19) are calculated, F-test criterion has the value:

$$
F_{a}=2,7762 \leq F_{t}(5,3)=9,01
$$

which shows that the resulting mathematical model (16) adequately describes the acceleration on the tool holder in the process of cutting by longitudinal turning. Another criterion that is used in the selection of the mathematical model is a multiple regression coefficient $R$ whose value is determined by the form:

$$
R=\sqrt{1-\frac{\sum_{j=1}^{N}\left(y_{j}^{E}-y_{j}^{R}\right)^{2}}{\sum_{j=1}^{N}\left(y_{j}^{E}-\bar{y}^{E}\right)^{2}}}
$$

Using data from Table 4 and by the expression (21) we obtain the value of the coefficient:

$$
R=0.999 \text {. }
$$

Thus, in both cases of checking of the model adequacy (Fisher criterion and multiple regression coefficient $R$ ), the results show that the resulting mathematical model in coded form (16), adequately describes the process of longitudinal turning with variable parameters $\sigma_{z}, n$ and $\delta$, i.e. the tool holder acceleration $a_{N A}$.

\section{EXPERIMENTAL RESULTS}

After adequacy of mathematical models tests, through all the previous analysis, it is now necessary expression (16) to translate the encoded form of the variables $\left(\mathrm{X}_{\mathrm{i}}\right)$ in the physical model with the actual process parameters $\left(\sigma_{\mathrm{z}}, \mathrm{n}, \delta\right)$ instead of coded.

Using expressions for the conversion to [3,5] and an additional translation of equality we get:

$X_{1}=0,01 \sigma_{z}-5,8$

$X_{2}=2,5 \delta-1,5$

$X_{3}=0,00476 n-1,333$

$X_{12}=0,0000476 \sigma_{z} n-0,0133 \sigma_{z}-0,027608 n+7,73314$

and including of the expression (16) and after ordering we get to the final form of the output function $Y=F_{i:}$ :

$$
\begin{aligned}
& Y=a_{N A}=3.74-0.0524 \sigma_{z}+1.2325 \delta-0.009 n \\
& +0.00002 \sigma_{z} n
\end{aligned}
$$



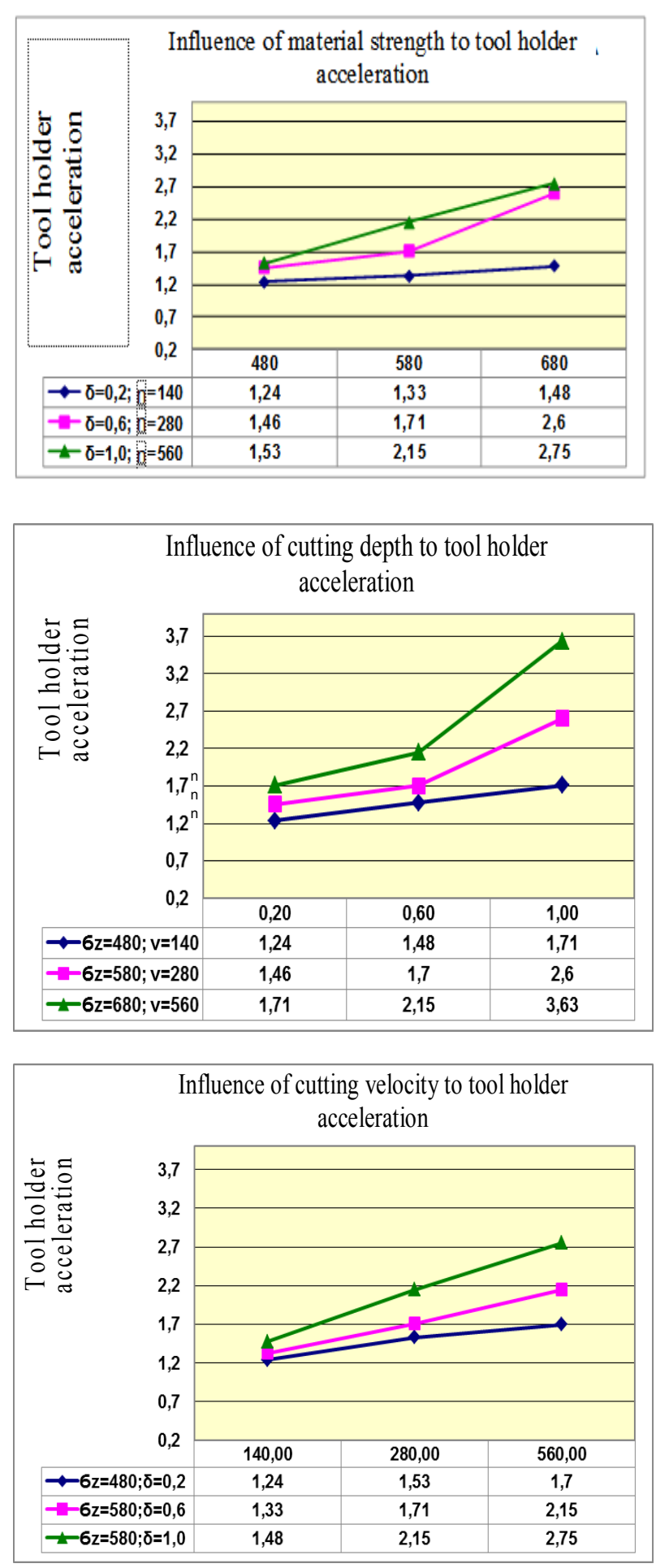

Figure 6. Graphic description of tool holder acceleration in the function of material, cutting velocity and cutting depth

The expression (23) represents the final mathematical model in the physical form for accelerations on the tool holder in the process of cutting by longitudinal turning $a_{N A}$, which was the main objective of this paper.

By simulating the model (23) in the graphics package "Graphis 2.9" varying parameter of values $\sigma_{z}$, $\mathrm{n}, \delta, 2 \mathrm{D}$ diagrams were obtained (Figure 6) thus providing an insight into the character and value of tool holder acceleration $a_{N A}$.

\section{CONCLUSION}

The research which is based on the performance of the experiment process of longitudinal turning by applying the appropriate measuring equipment was carried out, and by the analysis process and using the stochastic modeling, physical mathematical model for tool holder acceleration in the form of $a_{N A}=\mathrm{f}\left(\sigma_{z}, n, \delta\right)$ was obtained.

Research results and analysis have shown that: The resulting mathematical model for tool holder acceleration $a_{N A}$ adequately describes the process, which is explicitly confirmed by the criteria of adequacy (Fisher criterion and the criterion of multiple regression coefficient R).

By simulation of obtained mathematical model for tool holder acceleration $a_{N A}$ software package "Graphis $2.9^{\text {", }}$, the monitoring of the nature and value of the tool holder acceleration for mentioned parameters has been enabled.

Applied methods of modeling and simulation in this paper can be also used to define the optimal values of a large number of technological parameters of longitudinal turning process by using a mathematical model of higher order, and that would be primarily related to the minimization of tool holder acceleration with getting the product to the required quality and with a minimum energy consumption.

\section{REFERENCES}

[1] Dobler, H.-D., Warnwr, D., Urlich F.: Metal Cutting Technologies, Verlag Europa-Lehrmittel Nourney, Vollmer, Haan-Gruiten, 2003. (in Germany)

[2] Stanić, J.: Theory of Machining Processes, Mašinski fakultet Beograd, Beograd, 1994. (in Serbian)

[3] Jurković, M.: Mathematical modeling of engineering processes and systems, Mašinski fakultet Bihać, 1999. (in Croatian)

[4] Jovičić, M.: Cutting processes, Mašinski fakultet Beograd, Beograd, 1992. (in Serbian)

[5] Novkinić, B.: Influence of selfexcited vibrations on tool holder of turning machines with main rotational movement, M.Sc Thesis, Tehnički fakulatet Bihać, Bihać, 2013.

[6] Karabegović, I., Husak, E., Pašić, S.: Vibration analysis of tool holder during turning process, in: $14^{\text {th }}$ International Conference Mechanika 2009, Kaunas University of Technology, Lithuania, 2009. pp. 200-204.

[7] Doleček, V., Karabegović, I., Martinović, D., Jurković, M., Blagojević D., Bogdan Š., Bjelonja I.: Elastostatic Part 2, Tehnički Fakultet Bihać, 2004. str. 279-302. (in Bosnian)

[8] Jurković, M., Jurković, Z., Buljan, S.: The tribological state test in metal forming processes using experiment and modeling, Journal of Achievements in Materials and Manufacturing 
Engineering, Vol. 18, No. 1-2 September-October, pp. 384-385, 2006.

[9] Karabegović, I., Husak, E.: Mathematical modeling of deep drawing force with double reduction of wall thickness, Journal Mechanika, Vol. 70, No. 2, pp. 61-66, 2008.

[10] Adamović, D., Stefanović, M., Plančak M., Aleksandrović, S.: Analysis of change of total ironing force and friction force on punch at ironing, Journal for Technology of Plasticity, Vol. 33, No. 1-2, pp. 245-253, 2008.

[11] Mgwatu, M.I.: Integrated approach for optimising machining parameters, tool wear and surface quality in multi-pass turning operations, Advances in Production Engineering \& Management, Vol. 8, No. 4, pp. 209-218, 2013.

[12] Sekulic, M., Kovac, P., Gostimirovic, M., Kramar: Optimization of high-pressure jet assisted turning process by Taguchi method, Advances in Production Engineering \& Management, Vol. 8, No. 1, pp. 5-12, 2013.

\section{ЕКСПЕРИМЕНТАЛНА ИДЕНТИФИКАЦИЈА УБРЗАҢА НОСАЧА У ПРОЦЕСУ УЗДУЖНОГ РЕЗАњА}

\section{Исак Карабеговић, Бекир Новкинић, Ермин Хусак}

Пројектовање модерних производних система на којима би било могуће изводити најзахтјевније процесе резања захтјева анализу свих техничко - технолошких параметара процеса уз примјену научних метода, моделирања и дефинисања оптималних услова обрадних процеса и система.

Да би се обезбједило планирано функционисање алатних машина потребно је да оне буду у довољној мјери отпорне и стабилне на све утјецаје којима су изложене у процесу резања. Због великог броја утјецајних фактора на сам процес резања врло је тешко одредити најутјецајније параметре процеса резања помоћу аналитичког модела. Из тог разлога је потребно примјенити експериментална мјерења и анализу добијених резултата који ће се искористити за стварање подлоге при идентификацији сила резања, што је незамјењиво у развоју нових алатних машина и усавршавању постојећих обрадних система. Функција циља рада је пронаћи математички алгоритам убрзања носача алата $\left(a_{N A}=f\left(\sigma_{z}, v, \delta\right)\right)$ у функцији чврстоће обрађиваног материјала, брзине резања и дубине резања. У раду је извршено експериментално истраживање убрзања носача алата код токарења за три врте челика: 9SMn28, S355JOG3 и C45E.

Table 1. Physical values of the input influential parameters

\begin{tabular}{|c|c|c|c|c|}
\hline \multicolumn{2}{|c|}{ Influential quantities } & \multicolumn{2}{c|}{ Physical quantities of influential quantities } \\
\hline \multirow{4}{*}{ Physical quantities } & The level of variation & Minimal & Average & Maximal \\
\cline { 2 - 5 } & $x_{1}=\sigma_{z}$ & $480\left(\mathrm{~N} / \mathrm{mm}^{2}\right)$ & $580\left(\mathrm{~N} / \mathrm{mm}^{2}\right)$ & $680\left(\mathrm{~N} / \mathrm{mm}^{2}\right)$ \\
\cline { 2 - 5 } & $x_{2}=\delta$ & $0,2(\mathrm{~mm})$ & $0,6(\mathrm{~mm})$ & $1,0(\mathrm{~mm})$ \\
\cline { 2 - 5 } & $x_{3}=n=v$ & $140(\mathrm{o} / \mathrm{min})=14(\mathrm{~m} / \mathrm{min})$ & $280(\mathrm{o} / \mathrm{min})=26(\mathrm{~m} / \mathrm{min})$ & $560(\mathrm{o} / \mathrm{min})=53(\mathrm{~m} / \mathrm{min})$ \\
\hline
\end{tabular}

Table 2. Table of complete plan of the experiment

\begin{tabular}{|c|c|c|c|c|c|c|c|c|c|c|c|c|}
\hline \multirow{2}{*}{ 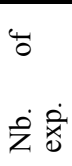 } & \multicolumn{3}{|c|}{ Physical values of parameters } & \multicolumn{8}{|c|}{ Coded values of parameters } & \multirow{2}{*}{$\begin{array}{l}\text { Exsp. } \\
\text { results } \\
Y_{j}=a_{N A} \\
{\left[\mathrm{~m} / \mathrm{s}^{2}\right]}\end{array}$} \\
\hline & $\begin{array}{c}x_{1}=\sigma_{z} \\
\left(\mathrm{~N} / \mathrm{mm}_{2}\right)\end{array}$ & $\begin{array}{l}x_{2}=\delta \\
\text { (mm) }\end{array}$ & $\begin{array}{c}x_{3}=n \\
(\% / m i n)\end{array}$ & $X_{0}$ & $X_{1}$ & $X_{2}$ & $X_{3}$ & $X_{1} X_{2}$ & $X_{2} X_{3}$ & $X_{1} X_{3}$ & $X_{1} X_{2} X_{3}$ & \\
\hline 1. & 480 & 0.2 & 140 & +1 & -1 & -1 & $\overline{-1}$ & +1 & +1 & +1 & -1 & 1.34 \\
\hline 2. & 680 & 1 & 560 & +1 & +1 & -1 & -1 & -1 & +1 & -1 & +1 & 1.5371 \\
\hline 3. & 480 & 0.2 & 140 & +1 & -1 & +1 & -1 & -1 & -1 & +1 & +1 & 1.4817 \\
\hline 4. & 680 & 1 & 560 & +1 & +1 & +1 & -1 & +1 & -1 & -1 & -1 & 2.716 \\
\hline 5. & 480 & 0.2 & 140 & +1 & -1 & -1 & +1 & +1 & -1 & -1 & +1 & 2.604 \\
\hline 6. & 680 & 1 & 560 & +1 & +1 & -1 & +1 & -1 & -1 & +1 & -1 & 1.4659 \\
\hline 7. & 480 & 0.2 & 140 & +1 & -1 & +1 & +1 & -1 & +1 & -1 & -1 & 2.7582 \\
\hline 8. & 680 & 1 & 560 & +1 & +1 & +1 & +1 & +1 & +1 & +1 & +1 & 3.8361 \\
\hline 9. & 580 & 0.6 & 280 & +1 & 0 & 0 & 0 & 0 & 0 & 0 & 0 & 2.15 \\
\hline 10. & 580 & 0.6 & 280 & +1 & 0 & 0 & $\overline{0}$ & 0 & 0 & 0 & 0 & 1.71 \\
\hline 11. & 580 & 0.6 & 280 & +1 & 0 & 0 & 0 & 0 & 0 & 0 & 0 & 1.70 \\
\hline 12. & 580 & 0.6 & 280 & +1 & 0 & 0 & $\overline{0}$ & 0 & 0 & 0 & 0 & 1.3 \\
\hline
\end{tabular}


Table 3. Coefficients' significance $\left(b_{i}\right)$

\begin{tabular}{|c|c|c|c|c|c|}
\hline $\begin{array}{c}\text { Coefficients } \\
b_{i}\end{array}$ & $\begin{array}{l}\text { Degree of } \\
\text { freedom } \\
\qquad f_{i}\end{array}$ & $\begin{array}{c}\text { The sum of } \\
\text { quadrants } S_{b i}^{2}\end{array}$ & $\begin{array}{l}\text { Ccalculated ratio, } \\
\text { F-test } \\
\mathrm{F}_{\mathrm{ri}}\end{array}$ & $\begin{array}{c}\text { Tabular value } \\
\mathrm{F}_{\mathrm{t}}\left(\mathrm{f}_{1}, \mathrm{f}_{2}\right)=\mathrm{F}_{\mathrm{t}}(1,3)\end{array}$ & .0气 \\
\hline $\mathrm{b}_{0}=2,044$ & $f_{0}=3$ & $S_{b 0}^{2}=50,135$ & $\mathrm{~F}_{\mathrm{r} 0}=446,04$ & 10,1 & $*$ \\
\hline $\mathrm{b}_{1}=0,184$ & $f_{1}=1$ & $S_{b 1}^{2}=0,270$ & $\mathrm{~F}_{\mathrm{r} 1}=2,409$ & 10,1 & - \\
\hline $\mathrm{b}_{2}=0,493$ & $f_{2}=1$ & $S_{b 2}^{2}=1,944$ & $F_{r 2}=17,28$ & 10,1 & $*$ \\
\hline $\mathrm{b}_{3}=0,461$ & $f_{3}=1$ & $S_{b 3}^{2}=0,1700$ & $\mathrm{~F}_{\mathrm{r} 3}=15,11$ & 10,1 & $*$ \\
\hline $\mathrm{b}_{12}=0,394$ & $f_{3}=1$ & $S_{b 12}^{2}=1,2418$ & $\mathrm{~F}_{\mathrm{r} 12}=11,03$ & 10,1 & $*$ \\
\hline$b_{13}=-0,193$ & $f_{3}=1$ & $S_{b 13}^{2}=0,316$ & $\mathrm{~F}_{\mathrm{r} 13}=2,810$ & 10,1 & - \\
\hline $\mathrm{b}_{23}=0,138$ & $f_{3}=1$ & $S_{b 23}^{2}=0,152$ & $\mathrm{~F}_{\mathrm{r} 23}=1,354$ & 10,1 & - \\
\hline $\mathrm{b}_{123}=0,160$ & $f_{3}=1$ & $S_{b 123}^{2}=0,204$ & $\mathrm{~F}_{\mathrm{r} 123}=1,820$ & 10,1 & - \\
\hline
\end{tabular}

Table 4. Data for testing multiple regression coefficient $R$

\begin{tabular}{|c|c|c|c|c|c|c|c|c|}
\hline \multirow{2}{*}{$\begin{array}{c}\text { Number } \\
\text { of } \\
\text { eksp. }\end{array}$} & \multicolumn{3}{|c|}{$\begin{array}{c}\text { Input } \\
\text { Values } \\
\end{array}$} & \multirow{2}{*}{$\begin{array}{c}\begin{array}{c}\text { Measuring } \\
\text { results }\end{array} \\
\boldsymbol{y}_{\boldsymbol{j}}=a_{N A}\end{array}$} & \multirow{2}{*}{$\begin{array}{c}\begin{array}{c}\text { Average } \\
\text { value }\end{array} \\
\bar{y}_{j}\end{array}$} & \multirow{2}{*}{$\frac{\text { Quadrat sum }}{\left(y_{j i}-\bar{y}_{j}\right)^{2}}$} & \multirow{2}{*}{$\frac{\text { Variance }}{S_{j}^{2}}$} & \multirow{2}{*}{$\begin{array}{c}\begin{array}{c}\text { Degree of } \\
\text { freedom }\end{array} \\
f_{j}\end{array}$} \\
\hline & $\begin{array}{c}\sigma_{z} \\
N / \mathrm{mm}^{2}\end{array}$ & $\begin{array}{c}\delta \\
\mathrm{mm}\end{array}$ & $\begin{array}{c}n \\
\% / \min \end{array}$ & & & & & \\
\hline 9 & 580 & 0,6 & 280 & 2,151 & 1,725 & 0,1810 & 0,06 & 3 \\
\hline 10 & 580 & 0,6 & 280 & 1,713 & 1,725 & 0,00014 & 0,00005 & 3 \\
\hline 11 & 580 & 0,6 & 280 & 1,708 & 1,725 & 0,00029 & 0,00001 & 3 \\
\hline 12 & 580 & 0,6 & 280 & 1,33 & 1,725 & 0,156 & 0,052 & 3 \\
\hline & & & & & & $\sum_{i=1} S_{j}^{2}=$ & 0,1120 & \\
\hline
\end{tabular}

